\title{
Anxiogenic, memory-impairing, pro-oxidant and pro-inflammatory effects of sodium benzoate in the mouse brain
}

\author{
Anthony Tope Olofinnade ${ }^{1,3(}$, Adejoke Yetunde Onaolapo $^{2 \oplus}$, Olakunle James Onaolapo ${ }^{3}$
}

'Lagos State University, Faculty of Basic Clinical Sciences, College of Medicine, Department of Pharmacology, Therapeutics and Toxicology, Ikeja - Lagos State

'Ladoke Akintola University of Technology, Behavioral Neuroscience/Neurobiology Unit, Department of Anatomy, Ogbomosho, Oyo State - Nigeria

${ }^{3}$ Ladoke Akintola University of Technology, Behavioral Neuroscience/Neuropharmacology Unit, Department of Pharmacology, Osogbo, Osun State - Nigeria

\begin{abstract}
Objective: Sodium benzoate $(\mathrm{NaB})$, a commonly used food additive, is effective in preventing deterioration and/or spoilage of foods and drinks. While there have been reports suggesting its potential use as an adjunct in schizophrenia management; there is a lack of information on its effects on the brain, especially when added to dry foods. This study examined the effects of NaB added to rodent feed on neurobehavior, antioxidant status, anti-inflammatory and apoptotic markers in mouse brain.

Method: Animals were divided into 4 groups of 10 mice each. Groups included normal control (fed with rodent chow) and 3 groups fed with $\mathrm{NaB}$ at 125, 250 and $500 \mathrm{mg} / \mathrm{kg}$, respectively, for eight weeks. Open field, elevated plus maze (EPM), Y-maze, and radial-arm maze behaviors were assessed on day 57, following animals were euthanized 24 hours after the behavioral test. Whole-brain homogenate processed for the assessment of antioxidant status, inflammatory/apoptotic markers, and acetylcholinesterase activity.

Results: The $\mathrm{NaB}$ diet altered body weight, open-field behaviors, working-memory, and anxiety indices. Brain antioxidant status, tumor necrosis factor-a and interleukin-10 decreased, while the malondialdehyde, caspase-3 level, and acetylcholinesterase activity increased.

Conclusion: The results of this study revealed that the addition of $\mathrm{NaB}$ at these concentrations to rodent chow was associated with memory loss, anxiety, oxidative stress and increased inflammatory/apoptotic effects suggesting vigilance in its use.
\end{abstract}

Keywords: Anxiety, cognition, inflammation, memory, neurobehavior, oxidative stress

\section{INTRODUCTION}

Food preservatives containing sodium benzoate $(\mathrm{NaB})$ have been used for decades to prevent deterioration or spoilage of foods and drinks due to the activities of microorganisms and enzymes (1). The use of a chemical agent as a food preservative presupposes that it is readily soluble, exhibits antimicrobial properties across

How to cite this article: Olofinnade AT, Onaolapo AY, Onaolapo OJ. Anxiogenic, memory-impairing, pro-oxidant and pro-inflammatory effects of sodium benzoate in the mouse brain. Dusunen Adam The Journal of Psychiatry and Neurological Sciences 2021;34:14-22.

Correspondence: Adejoke Onaolapo, Ladoke Akintola University of Technology, Behavioral Neuroscience/Neurobiology Unit, Department of Anatomy, Ogbomosho, Oyo State - Nigeria

E-mail: adegbayibiy@yahoo.com

Received: December 14, 2020; Revised: January 29, 2021; Accepted: March 16, 2021 
the $\mathrm{pH}$ range of the food, is non-toxic, and does not impart off-flavors $(1,2)$.

$\mathrm{NaB}$, the sodium salt of benzoic acid, is a preservative approved for use in foods (to prevent the growth of microbes such as fungi and bacteria that easily spoil foods) and pharmaceutical (as a preservative for liquid medicines, and lubricant for tablets) industries in several countries (1,3-6). Apart from its use in drinks, the use of $\mathrm{NaB}$ to preserve dried foods such as flour, fruits, and vegetables; and in biscuits, cakes and muffins are also widespread. Again, while moisture content is a major determinant of the efficacy of conventional food preservatives such as common salt, $\mathrm{NaB}$ had been shown to have a remarkable ability to preserve food or food ingredients regardless of moisture content; hence, foods with high moisture content such as tomato juice can still be well-preserved. However, $\mathrm{NaB}$ had also been found to be most suitable for foods and drinks that are in the acidic $\mathrm{pH}$ range, and its ability to preserve food in the low $\mathrm{pH}$ range contributes to its preservative property.

Different countries have regulations for the acceptable limits of $\mathrm{NaB}$ use, such as the United States of America approves its use under the generally accepted as safe status $(6,7)$. In Nigeria, the acceptable limits are set at $250 \mathrm{mg} / \mathrm{kg}$ (in drinks) in accordance with the Codex Alimentarius Commission guidelines $(8,9) . \mathrm{NaB}$ has also been assessed for its possible therapeutic effects with reports of health benefits derived from its pharmaceutical use (1,10-12).

In recent times, however, there has been also a growing body of knowledge highlighting the possible adverse effects of $\mathrm{NaB}$ when used as a food preservative $(1,5,13,14)$. In vivo and in vitro studies have associated the use of $\mathrm{NaB}$ with the development of oxidative stress, memory deficits, anxiety, motor impairment, testicular inflammation and apoptosis $(1,5,13,14)$. While a number of the studies examined the effects of $\mathrm{NaB}$ when added to drinking water $(1,5,15)$; there is a lack of scientific information on the effects of $\mathrm{NaB}$ when added to dry food. This study investigated the effect of $\mathrm{NaB}$, at different concentrations $(125,250$ and $500 \mathrm{mg} / \mathrm{kg}$ feed) on the brain of mice. We tested the hypothesis that at these concentrations (in food), $\mathrm{NaB}$ would have significant effects on neurobehavior, brain levels of oxidative stress, Caspase -3 activity, acetylcholinesterase activity, and inflammatory markers in mice.

\section{METHOD}

\section{Materials}

$\mathrm{NaB}$ (sourced from the Open market, Osogbo, Osun State, Nigeria). Tumor necrosis factor (TNF)- $\alpha$ and interleukin (IL)-10 assay kits (ENZO Life Sciences, U.S.A), Caspase-3 and Acetylcholinesterase assay kit (BioVision Inc. USA).

\section{Animals}

Adult mice (20-25 g) obtained from Empire farms in Osogbo, Nigeria were used for this study. Animals housing was a room kept at 23-25 0C with 12-hour light-dark cycle. Animal feed was obtained from TOP FEEDS ${ }^{\circledast}$ Nigeria Ltd. Animal care and use complies with protocols approved by the Faculty of Basic Medical Sciences LAUTECH ethical committee and the European Council Directive (EU2010/63).

\section{Feed}

The animal diet was made up of $11 \%$ fat and $58 \%$ carbohydrate. $\mathrm{NaB}$ was incorporated into standard rodent diet at $125(0.0125 \%), 250(0.025 \%$ and 500 $(0.05 \%) \mathrm{mg} / \mathrm{kg}$ feed.

\section{Experimental Methodology}

Adult male mice (40) were randomly assigned to 4 groups of 10 mice each The groups included: control, fed standard diet (SD), and three groups fed one of 3 concentrations of $\mathrm{NaB}$ included in the SD at 125, 250 and $500 \mathrm{mg} / \mathrm{kg}$ feed. $\mathrm{NaB}$ or SD was administered for eight weeks and body weight was measured weekly. Open field, elevated plus maze (EPM), Y-maze, and radial-arm maze behaviors were assessed on day 57, after which animals were euthanized (24 hours after the last behavioral test) as previously described (16). The brains were excised and homogenized for the assessment of malondialdehyde (MDA) levels, lipid profile, superoxide dismutase, total antioxidant capacity, TNF- $\alpha$, IL-10, caspase- 3 and acetylcholinesterase activity.

\section{Body Weight and Food Intake}

Weekly body weight and daily food intake measurements were carried out using an electronic weighing scale as previously described (16-18).

\section{Neurobehavioral Tests}

At the end of the experiment, animals were exposed to the neurobehavioral paradigms (EPM, Y-maze, Open field and radial-arm maze). Protocols for the care of animals before and during the test period are as previously described $(16,19)$.

\section{Open Field Test}

In the open-field arena, animals were allowed to go exploring for 10 minutes during which locomotor 
activity, number of rearing and grooming episodes were observed and scored to assess. The open-field box used for this study was a rectangular box made of white painted wood, measuring $36 \times 36 \times 26 \mathrm{~cm}$ as previously described (20-22).

\section{Memory Tests (Y-maze and radial arm maze)}

Mice were exposed to the Y-maze and radial-arm maze for 5 minutes, respectively, to assess spatial working memory. Arm entry sequences in the Y-maze were observed and recorded as described previously (23-25). Working-memory in the radial- arm maze is scored as previously described (26-28).

\section{Anxiety Model: Elevated Plus-maze}

The elevated plus-maze, a four-arm cross-shaped apparatus placed at right angles to each other, was used to measure anxiety-related behaviors. Anxiety behaviors were scored as previously described (23-25).

\section{Lipid Peroxidation (MDA)}

The lipid peroxidation kit was used to determine MDA levels as previously described (21-25).

\section{Antioxidant Activity}

Superoxide dismutase activity was assayed as described in a previous study (24). Total antioxidant capacity measures the numbaer of free radicals scavenged by the test solution in any biological sample (29-32). The total antioxidant capacity was based on the Trolox equivalent antioxidant capacity principle $(33,34)$.

\section{TNF- $\alpha$ and IL-10}

TNF- $\alpha$ and IL-10 were measured using enzyme-linked immunosorbent assay (ELISA) techniques with commercially available kits designed to measure the 'total' (bound and unbound) amount of the respective cytokines.

\section{Acetylcholinesterase Activity and Caspase-3 Levels}

Brain acetylcholinesterase and caspase- 3 activity were assayed according to the instructions provided by the manufacturers.

\section{Brain Homogenization}

Whole brains (5) were removed from the skulls of the animals, weighed and homogenized as described in an earlier study (16).

\section{Statistical Analysis}

Data were analyzed using Chris Rorden's ezANOVA for windows. One-factor ANOVA was used for analysis.
Tukey's honest significant difference test was used for intragroup and intergroup comparisons. Results were expressed as mean \pm standard error of mean (SEM) and $\mathrm{p}$ values less than 0.05 were considered statistically significant.

\section{RESULTS}

\section{$\mathrm{NaB}$ on Body Weight and Food Intake}

Figure 1 shows the effects of $\mathrm{NaB}$ on body weight (upper panel) and food consumption (lower panel). Body weight increased significantly $(\mathrm{F}[3,36]=9.970$, $\mathrm{p}=0.00063 \mathrm{SS}=0.35 \mathrm{MSe}=0.01)$ with $\mathrm{NaB}$ at $125 \mathrm{mg} / \mathrm{kg}$ feed compared to mice fed control diet. Intragroup comparisons $(\mathrm{NaB}$ vs. $\mathrm{NaB})$ revealed a significant decrease in body weight with $\mathrm{NaB}$ at 250 and $500 \mathrm{mg} / \mathrm{kg}$ compared to the group fed with $\mathrm{NaB}$ at $125 \mathrm{mg} / \mathrm{kg}$ feed.

Food consumption increased significantly (F [3, 36] $=2450.000, \mathrm{p}=0.00001 \mathrm{SS}=0.17 \mathrm{MSe}=0.01)$ with $\mathrm{NaB}$ at $125 \mathrm{mg} / \mathrm{kg}$ of feed in comparison to mice fed control diet. Intra group comparisons $(\mathrm{NaB}$ vs. $\mathrm{NaB})$ revealed a significant decrease in food consumption with $\mathrm{NaB}$ at 250 and $500 \mathrm{mg} / \mathrm{kg}$ compared to group fed $\mathrm{NaB}$ at 125 $\mathrm{mg} / \mathrm{kg}$ feed.

\section{$\mathrm{NaB}$ on Line Crossing and Rearing Activity}

Figure 2 shows the effect of $\mathrm{NaB}$ on the number of line crossings (upper panel) and rears (lower panel). Line crossing increased significantly $(F[3,36]=14.300$,

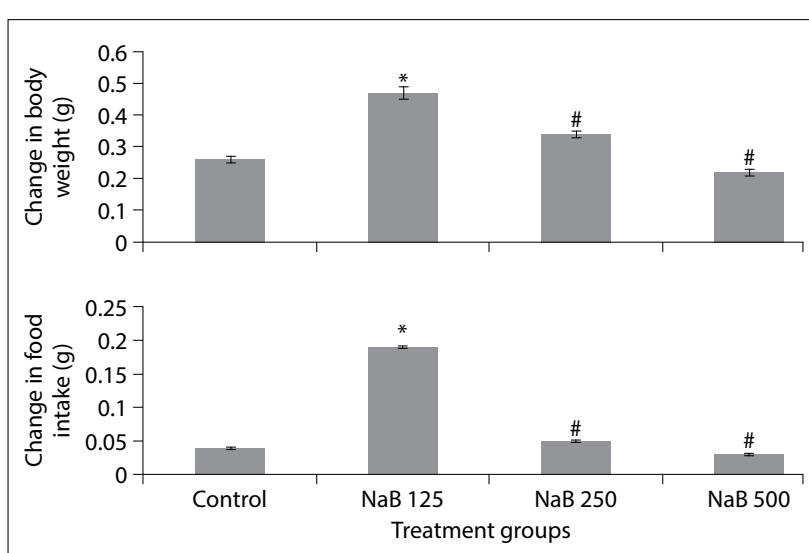

Figure 1. The effect of sodium benzoate on change in body weight (upper panel) and change in food intake (lower panel). Body weight and food intake increased significantly at the lowest concentration of NAB compared to control. The data were analyzed using One-way ANOVA. Each bar is Mean \pm SEM, ${ }^{*} \mathrm{p}<0.05$ treatment groups significantly different from control, $\# \mathrm{p}<0.05$ when $\mathrm{NaB} 250$ and $500 \mathrm{mg} / \mathrm{kg}$ are significantly different from $\mathrm{NaB} 125 \mathrm{mg} / \mathrm{kg}$ feed, number of mice/group=10, NaB: Sodium benzoate. 


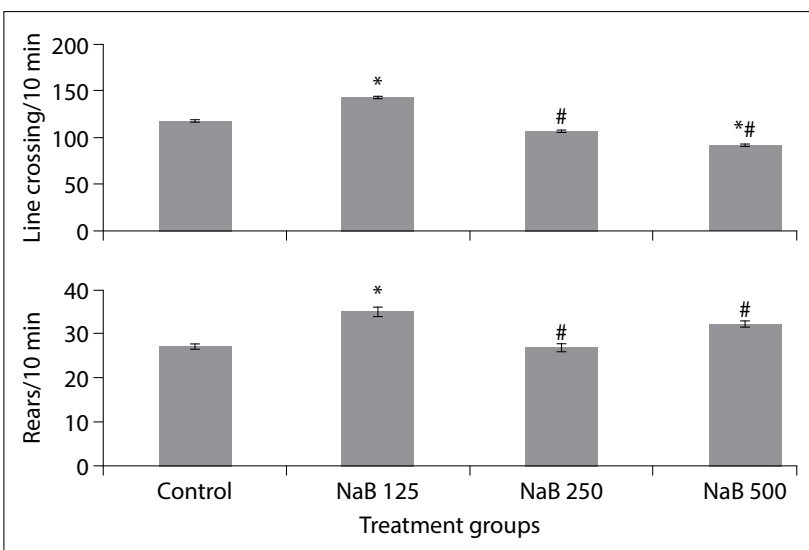

Figure 2. The effect of sodium benzoate on locomotor (upper panel) and rearing (lower panel) activity. Locomotor activity and rearing increased significantly at the lowest concentration of $\mathrm{NAB}$ compared to control. The data were analyzed using Oneway ANOVA. Each bar is Mean $\pm \mathrm{SEM},{ }^{*} \mathrm{p}<0.05$ treatment groups significantly different from control, \#p $<0.05$ when $\mathrm{NaB} 250$ and $500 \mathrm{mg} / \mathrm{kg}$ are significantly different from $\mathrm{NaB} 125 \mathrm{mg} / \mathrm{kg}$ feed, number of mice/group $=10, \mathrm{NaB}$ : Sodium benzoate.

$\mathrm{p}=0.000003 \mathrm{SS}=14151.88 \mathrm{MSe}=329.00)$ with $\mathrm{NaB}$ at 125 , and decreased at $500 \mathrm{mg} / \mathrm{kg}$ of feed compared to mice fed control diet. Intragroup comparisons $(\mathrm{NaB}$ vs. $\mathrm{NaB}$ ) revealed a significant decrease in line crossing with $\mathrm{NaB}$ at 250 and $500 \mathrm{mg} / \mathrm{kg}$ compared to the NaBfed group at $125 \mathrm{mg} / \mathrm{kg}$ feed.

Number of rears increased significantly (F [3, $36]=2.36, \mathrm{p}=0.0450, \mathrm{SS}=481.88, \mathrm{MSe}=68.10)$ with $\mathrm{NaB}$ at $125 \mathrm{mg} / \mathrm{kg}$ feed compared to mice fed control diet. Intra group comparisons $(\mathrm{NaB}$ vs. $\mathrm{NaB})$ revealed a significant decrease in rearing with $\mathrm{NaB}$ at 250 and $500 \mathrm{mg} / \mathrm{kg}$ compared to the group fed $\mathrm{NaB}$ at $125 \mathrm{mg} / \mathrm{kg}$ feed.

\section{$\mathrm{NaB}$ on Self-grooming}

Figure 3 shows the effect of $\mathrm{NaB}$ on the number of selfgrooming episodes. Number of grooming episodes increased significantly $(\mathrm{F}[3,36]=4.300, \mathrm{p}=0.0105$, $\mathrm{SS}=71.48 \mathrm{MSe}=5.51)$ with $\mathrm{NaB}$ at 125 and decreased at $250 \mathrm{mg} / \mathrm{kg}$ feed compared to mice fed control diet. Intragroup comparisons $(\mathrm{NaB}$ vs. $\mathrm{NaB})$ revealed a significant decrease in self-grooming with $\mathrm{NaB}$ at 250 and $500 \mathrm{mg} / \mathrm{kg}$ compared to the NaB-fed group at 125 $\mathrm{mg} / \mathrm{kg}$ feed.

\section{$\mathrm{NaB}$ on Working Memory in the $\mathrm{Y}$ - and Radial-arm Maze}

Figure 4 shows the effects of $\mathrm{NaB}$ on memory scores in the Y-(upper panel) and radial-arm (lower panel) maze. Memory scores in the $\mathrm{Y}$ maze decreased significantly ( $\mathrm{F}$ $[3,36]=6.540, \mathrm{p}=0.001204 \mathrm{SS}=1844.35 \mathrm{MSe}=93.96)$ with

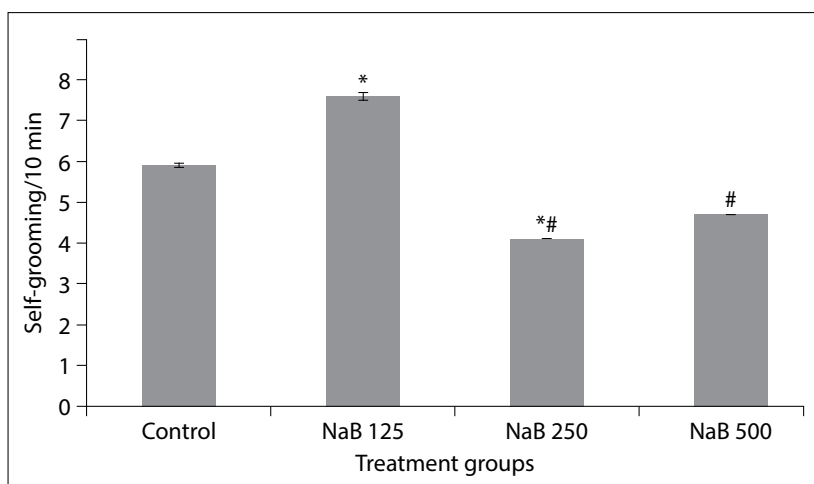

Figure 3. The effect of sodium benzoate on self-grooming. Grooming increased significantly at the lowest concentration of NAB compared to control. The data were analyzed using Oneway ANOVA. Each bar is Mean \pm SEM, ${ }^{*} \mathrm{p}<0.05$ treatment groups significantly different from control, $\# \mathrm{p}<0.05$ when $\mathrm{NaB} 250$ and $500 \mathrm{mg} / \mathrm{kg}$ are significantly different from $\mathrm{NaB} 125 \mathrm{mg} / \mathrm{kg}$ of feed, number of mice/group=10, NaB: Sodium benzoate.

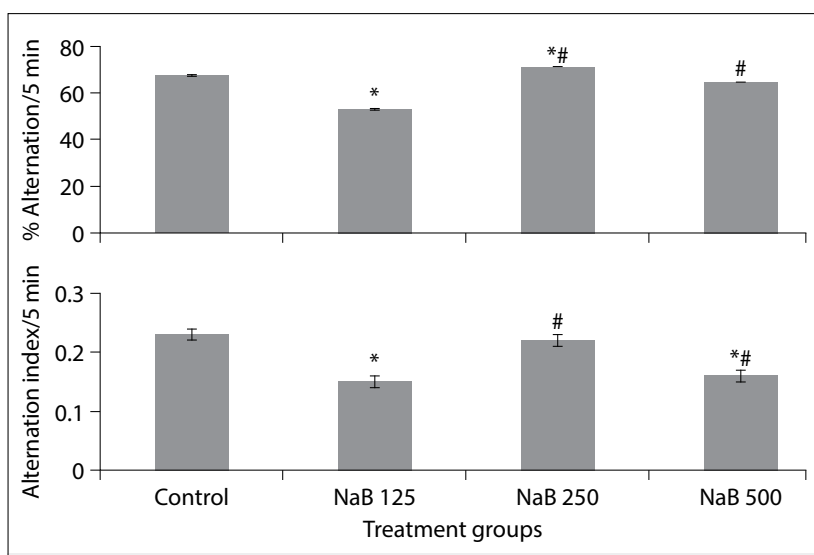

Figure 4. Effect of sodium benzoate on working memory in the Y- (upper panel) and radial arm (lower panel) maze. A maze-dependent modulation of working memory scores was observed. The data analysed using One-way ANOVA. Each bar is Mean $\pm \mathrm{SEM},{ }^{*} \mathrm{p}<0.05$ treatment groups significantly different from control, $\# \mathrm{p}<0.05$ when $\mathrm{NaB} 250$ and $500 \mathrm{mg} / \mathrm{kg}$ are significantly different from $\mathrm{NaB} 125 \mathrm{mg} / \mathrm{kg}$ feed, number of mice/ group $=10, \mathrm{NaB}$ : Sodium benzoate.

$\mathrm{NaB}$ at $125 \mathrm{mg} / \mathrm{kg}$ feed and increased with $\mathrm{NAB}$ at 250 $\mathrm{mg} / \mathrm{kg}$ feed compared to mice fed control diet. Intragroup comparisons $(\mathrm{NaB}$ vs. $\mathrm{NaB})$ revealed a significant increase in memory scores with $\mathrm{NaB}$ at 250 and $500 \mathrm{mg} /$ $\mathrm{kg}$ compared to the $\mathrm{NaB}$-fed group at $125 \mathrm{mg} / \mathrm{kg}$ feed.

Memory scores in the radial-arm maze decreased significantly $(\mathrm{F}[3,36]=4.590, \mathrm{p}=0.0081, \mathrm{SS}=0.04$ $\mathrm{MSe}=0.01$ ) with $\mathrm{NaB}$ at 125 and $500 \mathrm{mg} / \mathrm{kg}$ feed compared to mice fed control diet. Intragroup comparisons ( $\mathrm{NaB}$ vs. $\mathrm{NaB}$ ) revealed a significant increase in memory scores with $\mathrm{NaB}$ at 250 and $500 \mathrm{mg} /$ $\mathrm{kg}$ compared to the $\mathrm{NaB}$-fed group at $125 \mathrm{mg} / \mathrm{kg}$ feed. 


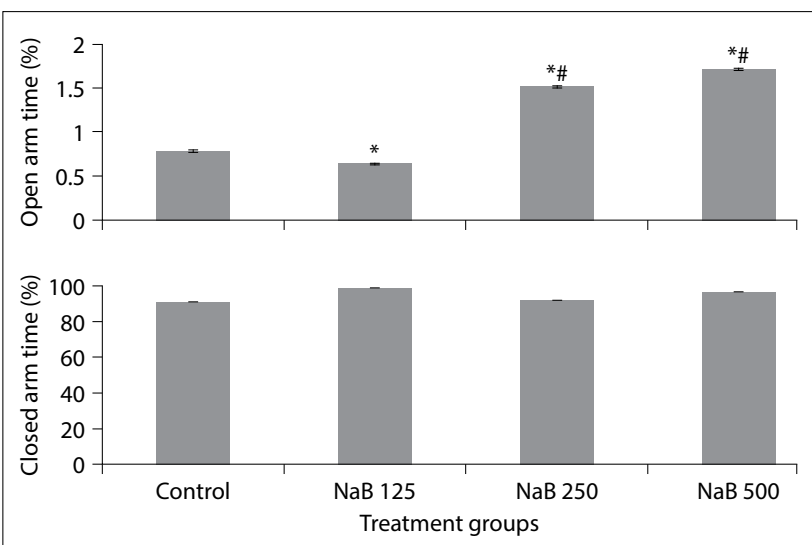

Figure 5. The effect of sodium benzoate on time spent in the open (upper panel) and closed (lower panel) arm of the elevated plus-maze. A concentration-dependent decrease in anxiety-related behaviors was observed. Data were analyzed using One-way ANOVA. Each bar is Mean \pm SEM, ${ }^{*} \mathrm{p}<0.05$ treatment groups significantly different from control, \#p<0.05 when $\mathrm{NaB} 250$ and $500 \mathrm{mg} / \mathrm{kg}$ are significantly different from $\mathrm{NaB} 125 \mathrm{mg} / \mathrm{kg}$ feed, number of mice/group $=10, \mathrm{NaB}$ : Sodium benzoate.

\section{$\mathrm{NaB}$ on Anxiety-Related Behaviors}

Figure 5 shows the effects of $\mathrm{NaB}$ on time spent in the open (upper panel) or closed (lower panel) arm of the elevated plus-maze. Open arm time decreased significantly $(\mathrm{F}[3,36]=2.450, \mathrm{p}=0.02300, \mathrm{SS}=1032.00$ $\mathrm{MSe}=85.17)$ with $\mathrm{NaB}$ at $125 \mathrm{mg} / \mathrm{kg}$ feed and increased at 250 and $500 \mathrm{mg} / \mathrm{kg}$ feed compared to mice fed control diet. Intragroup comparisons $(\mathrm{NaB}$ vs. $\mathrm{NaB})$ revealed a significant increase in open arm time with $\mathrm{NaB}$ at 250 and $500 \mathrm{mg} / \mathrm{kg}$ compared to NaB-fed group at $125 \mathrm{mg} /$ $\mathrm{kg}$ feed.

Closed arm time did not differ significantly ( $\mathrm{F}[3$, 36] $=1.081 \mathrm{p}=0.0795, \mathrm{SS}=22.70 \mathrm{MSe}=2.46)$ in any of the $\mathrm{NaB}$-fed groups compared to the mice fed control diet or the other concentrations of $\mathrm{NaB}$.

\section{$\mathrm{NaB}$ on MDA Levels and Antioxidant Status}

Table 1 shows the effect of $\mathrm{NaB}$ on lipid peroxidation levels and antioxidant status. Brain MDA levels increased significantly $(\mathrm{F}[3,36]=2154, \mathrm{p}<0.0001$,
$\mathrm{SS}=9668.49 \mathrm{MSe}=2.56)$ with $\mathrm{NaB}$ at 125,250 and 500 $\mathrm{mg} / \mathrm{kg}$ feed compared to the mice fed control diet. Intragroup comparisons $(\mathrm{NaB}$ vs. $\mathrm{NaB})$ revealed a significant increase in lipid peroxidation levels with $\mathrm{NaB}$ at 250 and a significant decrease at $500 \mathrm{mg} / \mathrm{kg}$ compared to the NaB-fed group at $125 \mathrm{mg} / \mathrm{kg}$ feed.

Brain superoxide dismutase activity increased significantly $(\mathrm{F}[3,36]=45.000, \mathrm{p}=0.001, \mathrm{SS}=25.26$ $\mathrm{MSe}=0.06$ ) with $\mathrm{NaB}$ at 125 and $250 \mathrm{mg} / \mathrm{kg}$ and decreased at $500 \mathrm{mg} / \mathrm{kg}$ feed compared to control diet. Intragroup comparisons $(\mathrm{NaB}$ vs. $\mathrm{NaB})$ revealed a significant increase in superoxide dismutase activity with $\mathrm{NaB}$ at 250 and a significant decrease at $500 \mathrm{mg} / \mathrm{kg}$ compared to the NaB-Fed group at $125 \mathrm{mg} / \mathrm{kg}$ feed.

Brain total antioxidant capacity decreased significantly $(\mathrm{F}[3,36]=250.000, \mathrm{p}=0.001 \mathrm{SS}=388.61$ $\mathrm{MSe}=0.03$ ) with $\mathrm{NaB}$ at 125,250 and $500 \mathrm{mg} / \mathrm{kg}$ compared to the mice fed control diet. Intra group comparisons $(\mathrm{NaB}$ vs. $\mathrm{NaB}$ ) revealed a significant increase in total antioxidant capacity with $\mathrm{NaB}$ at 250 and $500 \mathrm{mg} / \mathrm{kg}$ compared to the NaB-fed group at 125 $\mathrm{mg} / \mathrm{kg}$ feed.

\section{Sodium Benzoate on Inflammatory Markers, Brain Acetylcholinesterase and Caspase- 3 Levels}

Table 2 shows the effect of NaB on IL-10, TNF- $\alpha$, acetylcholinesterase and caspase- 3 levels. Brain TNF- $\alpha$ levels decreased significantly $(\mathrm{F}[3,36]=102, \mathrm{p}=0.001$, $\mathrm{SS}=6373.86 \mathrm{MSe}=0.45)$ with $\mathrm{NaB}$ at 125 and $250 \mathrm{mg} /$ $\mathrm{kg}$ feed compared to the mice fed control diet. Intragroup comparisons $(\mathrm{NaB}$ vs. $\mathrm{NaB})$ revealed a significant increase in TNF- $\alpha$ level with $\mathrm{NaB}$ at 250 and $500 \mathrm{mg} / \mathrm{kg}$ compared to the NaB-fed group at 125 $\mathrm{mg} / \mathrm{kg}$ feed.

Brain IL-10 levels decreased significantly (F [3, $36]=50.54, \mathrm{p}=0.0001, \mathrm{SS}=278.13 \mathrm{MSe}=0.13$ ) with $\mathrm{NaB}$ at 125,250 and $500 \mathrm{mg} / \mathrm{kg}$ of feed compared to the mice fed control diet. Intragroup comparisons ( $\mathrm{NaB}$ vs. $\mathrm{NaB}$ ) revealed a significant increase in IL-10 levels with $\mathrm{NaB}$ at 250 and $500 \mathrm{mg} / \mathrm{kg}$ compared to the $\mathrm{NaB}$-fed group at $125 \mathrm{mg} / \mathrm{kg}$ feed.

Table 1: Oxidative stress parameters and antioxidant status

\begin{tabular}{lccc} 
Groups & MDA nmol/g & SOD U/mg/protein & TAC (TE mg/protein) \\
\hline Control & $8.13 \pm 0.20$ & $1.42 \pm 0.03$ & $6.30 \pm 0.02$ \\
NaB 125 & $32.45 \pm 0.28^{*}$ & $3.56 \pm 0.04^{*}$ & $1.98 \pm 0.01^{*}$ \\
NaB 250 & $46.3 \pm 0.22^{* *}$ & $4.36 \pm 0.02^{* *}$ & $3.15 \pm 0.01^{* *}$ \\
NaB 500 & $12.32 \pm 0.11^{* \#}$ & $0.98 \pm 0.01^{* \#}$ & $3.45 \pm 0.02^{* \#}$ \\
\hline
\end{tabular}

The data were analyzed using one-way ANOVA. Values are presented as Mean $\pm 95 \%$ SEM, ${ }^{*} p<0.05$ treatment groups significantly different from control, ${ }^{\#} p<0.05$ when NaB 250 and 500 mg/kg are significantly different from NaB 125 mg/kg of feed, number of mice/group=10, NaB: Sodium Benzoate, MDA: Malondialdehyde, SOD: superoxide dismutase, TAC: Total antioxidant capacity, TE: Trolox equivalent 
Table 2: Tumour necrosis factor- $a$, Interleukin-10, acetylcholinesterase and caspase-3

\begin{tabular}{lcccc} 
Groups & TNF-a ng/g/protein & IL-10 pg/mg/protein & ACHenmol/mg & Caspase-3 (ng/mg) \\
\hline Control & $40.31 \pm 0.23$ & $24.12 \pm 0.10$ & $36.35 \pm 1.60$ & $0.30 \pm 0.02$ \\
NaB 125 & $24.22 \pm 0.15^{*}$ & $14.15 \pm 0.20^{*}$ & $40.20 \pm 1.10^{*}$ & $0.35 \pm 0.02^{*}$ \\
NaB 250 & $29.31 \pm 0.18^{* *}$ & $18.60 \pm 0.22^{* \#}$ & $45.35 \pm 1.60^{* \#}$ & $0.58 \pm 0.04^{* *}$ \\
NaB 500 & $42.15 \pm 0.23^{* *}$ & $17.98 \pm 0.01^{* *}$ & $40.30 \pm 1.60^{*}$ & $0.39 \pm 0.03^{*}$ \\
\hline
\end{tabular}

Data analysed using one-way ANOVA. Values are presented as Mean $\pm 95 \%$ SEM, ${ }^{*} \mathrm{p}<0.05$ treatment groups significantly different from control, $\mathrm{p}<0.05$ when NaB 250 and $500 \mathrm{mg} / \mathrm{kg}$ are significantly different from NaB $125 \mathrm{mg} / \mathrm{kg}$ feed, number of mice/group=10, NaB: Sodium Benzoate, TNF-a: Tumour necrosis factor -alpha, IL-10: Interleukin -10: ACHe: Acetylcholinesterase

Brain acetylcholinesterase $(\mathrm{ACHe})(\mathrm{F}[3,36]=32.00$, $\mathrm{p}=0.0001, \mathrm{SS}=15.12 \mathrm{MSe}=0.04)$ and caspase -3 ( $\mathrm{F}[3$, 36] $=25.000, \mathrm{p}=0.001, \mathrm{SS}=119.47 \mathrm{MSe}=2.22$ ) activity increased significantly with $\mathrm{NaB}$ at 125, 250 and 500 $\mathrm{mg} / \mathrm{kg}$ feed compared to the mice fed control diet. Intragroup comparisons $(\mathrm{NaB}$ vs. $\mathrm{NaB})$ revealed a significant decrease in ACHe and Caspase-3 activity with $\mathrm{NaB}$ at $250 \mathrm{mg} / \mathrm{kg}$ compared to the $\mathrm{NaB}$-fed group at $125 \mathrm{mg} / \mathrm{kg}$ feed.

\section{DISCUSSION}

In this study, the effect of sodium benzoate on body weight, food consumption, behavioral parameters, oxidative stress parameters, inflammatory and apoptotic markers were examined in mice. Results showed that sodium benzoate, when incorporated into dry rodent feed was associated with; a) an increase in body weight and food consumptionat $125 \mathrm{mg} / \mathrm{kg}$ feed, b) a decrease in line crossing and an increase in rearing at $125 \mathrm{mg} / \mathrm{kg}, \mathrm{d}$ ) an increase in self-grooming at 125 , and a decrease at $250 \mathrm{mg} / \mathrm{kg}, \mathrm{d}$ ) a decrease in memory scores in both the $\mathrm{Y}$ - and radial arm- maze memory, e) anxiogenic response at $125 \mathrm{mg} / \mathrm{kg}$ feed, $\mathrm{f}$ ) increase in brain levels of MDA, acetylcholinesterase and caspase-3 activity, g) increase in SOD activity at 125, 250 and a decrease at $500 \mathrm{mg} / \mathrm{kg}$ feed, h) decrease brain TAC and; i) a decrease in brain levels of TNF- $\alpha$ and IL-10.

Feeding mice with NAB for 8 weeks, as observed in this study, was associated with an increase in body weight and food consumption at the lowest concentration. The effects of NAB on body weight have been studied severally $(15,35,36)$ with varying results. Griffith (35) reported that feeding zebrafish with a benzoate diet at $1.5,2.0$ or $2.5 \%$ (significantly higher concentrations than those used in this study) did not significantly alter body weight (compared to controls), corroborating the results of this study when sodium benzoate diet was consumed at the higher concentrations. In a study in which $t$ sodium benzoate was administered daily in distilled water at much lower concentrations than those used in this study, a time and concentration-dependent decrease in body weight was observed irrespective of sex (15). The results of our study and the other studies show that the effect of NAB on body weight dependens on concentration, mode of administration and duration of administration. Food intake increased at $125 \mathrm{mg} / \mathrm{kg}$ feed and showed no significant difference from control at the other concentrations. It has been reported that $\mathrm{NAB}$ reduces feed intake (37). Although there have been reports of no significant effect when NAB was administered by gavage (36). Overall, the results show that an increase in food consumption corresponds to an increase in weight, suggesting that NAB likely increases the palatability of food at this concentration. There was a visual decrease in food consumption and body weight at higher concentrations, probably suggesting that the inclusion of NAB to diet at these concentrations possibly altered food palatability. While preservation of the freshness and taste of food (due to the presence of NAB) might preserve or maintain its palatability, it is not impossible for NAB to affect palatability by the utilization of other mechanisms.

In this study, incorporation of NAB into standard rodent diet was associated with a concentrationdependent decrease in line crossing; rearing, and grooming behaviors, although the decrease in rearing and grooming was observed at 250 and $500 \mathrm{mg} / \mathrm{kg}$ feed were only visual. Also, an anxiogenic response at 125 $\mathrm{mg} / \mathrm{kg}$ feed was observed along with a decrease in memory scores in both the Y- $(125 \mathrm{mg} / \mathrm{kg})$ and radialarm (125 and $250 \mathrm{mg} / \mathrm{kg}$ feed) maze. The neurobehavioral effects of NAB have been reported in a few studies (1,10,38-40). In this study, the results of line crossing, rearing, and grooming behaviors suggest an initial central stimulating effect at the lowest concentration, followed by a central inhibitory response at the higher concentrations. While there have been reports of no significant difference in locomotor activity of pups exposed to NAB in-utero $(37,41)$; there have been reports suggesting an alteration in motor activity 
in rats administered NAB dissolved in distilled water daily for 4 weeks (39) and a decrease in locomotor activity in the embryo and larvae of zebrafish, although the embryos were more sensitive to NAB (42). The induction of either a central inhibitory or excitatory response is linked to NAB's ability to pass through the blood-brain-barrier and alter or modulate neurotransmitter response. Studies in zebrafish have demonstrated that in-utero exposure to $\mathrm{NAB}$ altered brain development, resulting in a decrease in tactile sensitivity frequencies of touch-related movements (43). This suggests that it either crosses the underdeveloped blood- brain-barrier or damages it to gain access into the brain. Its effects on brain neurotransmitters have also been examined $(39,41,42)$. While there have been reports that it does not affect the levels of brain monoamines $(39,41)$, Chen et al. (42) reported that treatment of zebrafish with $\mathrm{NAB}$, dosedependently downregulated the expression of dopamine transporter and tyrosine hydroxylase in neurons of the ventral diencephalon, associating this with the decrease in locomotor activity observed. In our study, the increase in open field behaviors observed at $125 \mathrm{mg} / \mathrm{kg}$ feed could be due to the increase in dopamine receptor activity, while at the higher concentrations, due to the inhibition of dopamine receptor activity or ocuring neurotransmitter response.

In this study, working-memory impairment was observed with $\mathrm{NAB}$ at $125 \mathrm{mg} / \mathrm{kg}$ in the $\mathrm{Y}$-maze and at 125 and $500 \mathrm{mg} / \mathrm{kg}$ in the radial-arm maze. This confirms the results of a study by Khoshnoud et al. (1) that reported impairment of memory following subchronic oral administration of NAB at $0.56,1.125$, and $2.25 \mathrm{mg} / \mathrm{mL}$. Modi et al. (40), on the other hand reported that in-vivo metabolism of cinnamon (after oral administration in mice) results in NAB production, which was suggested to have a memory-enhancing effect (40). In this study, a significant decrease in acetylcholinesterase activity was observed, contrary to the reports of Khoshnoud et al. (1), suggesting that the memory impairment observed in this study could be attributed to an increase in acetylcholinesterase activity in addition to increased brain oxidative stress(evidenced by an increase in lipid peroxidation and a decrease in total antioxidant capacity) which was observed in this study. Since then, brain oxidative stress has been linked to the development of agingrelated memory deficits $(44,45)$.

In the study, $\mathrm{NAB}$ administration decreased brain levels of TNF- $\alpha /$ IL-10 and increased brain levels of caspase-3. Its effects on the pro-inflammatory marker
TNF- $\alpha$ confirms the result of Brahmachari et al (10), who reported the inhibition of lipopolysaccharide-induced expression of proinflammatory cytokines (TNF- $\alpha$ ) and inhibition of nuclear factor kappa B (NF- $\kappa \mathrm{B})$, an important transcription factor that regulates innate immunity by NAB. The authors attributed the antiinflammatory activity of NAB to the inhibition of NF-Kb (10). The effects on caspase- 3 confirms the result of a study by El-Shennawy et al. (5) that observed increased apoptotic activity in the testis of rats which were administered NAB dissolved in distilled water.

A limitation of this study is the fact that mice were utilized in conducting the experiments; therefore, caution is required in extrapolating the findings to humans. Also, the duration of the study is such that it may not necessarily reflect the effects of long-term consumption of NAB in humans.

While the therapeutic benefits of NAB have been reported severally, the results of this study revealed that chronic ingestion of $\mathrm{NAB}$ at these concentrations was associated with memory loss, anxiety, oxidative stress, increased inflammatory and apoptotic effects suggesting caution in its use.

\begin{tabular}{|c|c|c|}
\hline \multicolumn{2}{|c|}{ Contribution Categories } & \multirow{2}{*}{$\begin{array}{l}\text { Author Initials } \\
\text { A.T.O., A.Y.O., O.J.O. }\end{array}$} \\
\hline \multirow{3}{*}{ Category 1} & Concept/Design & \\
\hline & Data acquisition & A.T.O., A.Y.O., O.J.O. \\
\hline & Data analysis/Interpretation & A.Y.O., O.J.O. \\
\hline \multirow{2}{*}{ Category 2} & Drafting manuscript & A.T.O., A.Y.O., O.J.O. \\
\hline & Critical revision of manuscript & A.T.O., A.Y.O., O.J.O. \\
\hline Category 3 & Final approval and accountability & A.T.O., A.Y.O., O.J.O. \\
\hline \multirow{2}{*}{ Other } & Technical or material support & A.T.O., A.Y.O., O.J.O. \\
\hline & Supervision & N/A \\
\hline
\end{tabular}

Ethics Committee Approval: Animal care and use complied with protocols approved by Ladoke Akintola University of Technology ethical committees and the European Council Directive (EU2010/63).

Informed Consent: Not applicable.

Peer-review: Externally peer-reviewed.

Conflict of Interest: None declared.

Financial Disclosure: None declared.

\section{REFERENCES}

1. Khoshnoud MJ, Siavashpour A, Bakhshizadeh M, Rashedinia M. Effects of sodium benzoate, a commonly used food preservative, on learning, memory, and oxidative stress in brain of mice. J Biochem Mol Toxicol 2018; 32:e22022.

2. Lucera A, Costa C, Conte A, Del Nobile MA. Food applications of natural antimicrobial compounds. Front Microbiol 2012; 3:287. 
3. Pongsavee M. Effect of sodium benzoate preservative on micronucleus induction, chromosome break, and Ala40Thr superoxide dismutase gene mutation in lymphocytes. Biomed Res Int 2015; 2015:103512.

4. Yadav A, Kumar A, Das M, Tripathi A. Sodium benzoate, a food preservative, affects the functional and activation status of splenocytes at non cytotoxic dose. Food Chem Toxicol 2016; 88:40-47.

5. El-Shennawy L, Kamel MAE, Khalaf AHY, Yousef MI. Dosedependent reproductive toxicity of sodium benzoate in male rats: Inflammation, oxidative stress and apoptosis. Reprod Toxicol 2020; 98:92-98.

6. Lennerz BS, Vafai SB, Delaney NF, Clish CB, Deik AA, Pierce KA, et al. Effects of sodium benzoate, a widely used food preservative, on glucose homeostasis and metabolic profiles in humans. Mol Genet Metab 2015; 114:73-79.

7. United States Food and Drug Administration. Data on benzene in soft drinks and other beverages. https://wayback.archiveit.org/7993/20170112012123/https:/www.fda.gov/Food/ FoodborneIllnessContaminants/ChemicalContaminants/ ucm055815.htm. Accessed January 12, 2021.

8. World Health Organization. Codex Alimentarius Commission Procedural Manual; JOINT FAO/WHO Food Standards Programme. http://www.fao.org/3/i3243e/i3243e.pdf. Accessed January 12, 2021.

9. Ifijeh M. NIFST Aligns with FG, Says Benzoate is Safe as Preservatives. https://www.thisdaylive.com/index. php/2017/04/06/nifst-aligns-with-fg-says-benzoate-is-safe-aspreservatives/. Accessed January 12, 2021.

10. Brahmachari S, Jana A, Pahan K. Sodium benzoate, a metabolite of cinnamon and a food additive, reduces microglial and astroglial inflammatory responses. J Immunol 2009; 183:5917-5927.

11. Yucel A, Ozyalcin S, Talu GK, Yucel EC, Erdine S. Intravenous administration of caffeine sodium benzoate for postdural puncture headache. Reg Anesth Pain Med 1999; 24:51-54.

12. Lane HY, Lin CH, Green MF, Hellemann G, Huang CC, Chen $\mathrm{PW}$, et al. Add-on treatment of benzoate for schizophrenia: a randomized, double-blind, placebo-controlled trial of D-amino acid oxidase inhibitor. JAMA Psychiatry 2013; 70:1267-1275.

13. Yetuk G, Pandir D, Bas H. Protective role of catechin and quercetin in sodium benzoate-induced lipid peroxidation and the antioxidant system in human erythrocytes in vitro. ScientificWorldJournal 2014; 2014:874824.

14. Beezhold BL, Johnston CS, Nochta KA. Sodium benzoate-rich beverage consumption is associated with increased reporting of ADHD symptoms in college students: a pilot investigation. J Atten Disord 2014; 18:236-241.

15. Priya RJ, Sridhar R, Balachandran C, Manohar, BM. Effect of sodium benzoate treatment on body weight of Wistar rats. Indian Vet J 2010; 87:303-304.

16. Onaolapo AY, Ayeni OJ, Ogundeji MO, Ajao A, Onaolapo OJ, Owolabi AR. Subchronic ketamine alters behaviour, metabolic indices and brain morphology in adolescent rats: Involvement of oxidative stress, glutamate toxicity and caspase-3-mediated apoptosis. J Chem Neuroanat 2019; 96:22-33.
17. Onaolapo OJ, Onaolapo AY, Akanmu MA, Olayiwola G. Changes in spontaneous working-memory, memory-recall and approachavoidance following "low dose" monosodium Glutamate in mice. AIMS Neurosci 2016; 3:317-337.

18. Onaolapo AY, Onaolapo OJ, Nwoha PU. Aspartame and the hippocampus: Revealing a bi-directional, dose/time-dependent behavioural and morphological shift in mice. Neurobiol Learn Mem 2017; 139:76-88.

19. Olofinnade AT, Onaolapo TM, Oladimeji S, Fatoki AM, Balogun CI, Onaolapo AY, et al. An Evaluation of the effects of pyridoxal phosphate in chlorpromazineinduced parkinsonism using mice. Cent Nerv Syst Agents Med Chem 2020; 20:13-25.

20. Onaolapo AY, Onaolapo OJ, Nwoha PU. Methyl aspartylphenylalanine, the pons and cerebellum in mice: An evaluation of motor, morphological, biochemical, immunohistochemical and apoptotic effects. J Chem Neuroanat 2017; 86:67-77.

21. Onaolapo OJ, Onaolapo AY, Omololu TA, Oludimu AT, SegunBusari T, Omoleke T. Exogenous testosterone, aging, and changes in behavioral response of gonadally intact male mice. J Exp Neurosci 2016; 10:59-70.

22. Onaolapo AY, Odetunde I, Akintola AS, Ogundeji MO, Ajao A, Obelawo AY, et al. Dietary composition modulates impact of food-added monosodium glutamate on behaviour, metabolic status and cerebral cortical morphology in mice. Biomed Pharmacother 2019; 109:417-428.

23. Onaolapo AY, Olawore OI, Yusuf FO, Adeyemo AM, Adewole IO, Onaolapo OJ. Oral monosodium glutamate administration differentially affects novelty-induced behaviors, behavioral despair and place preference in male and female mice. Current Psychopharmacol 2019; 8:130-145.

24. Onaolapo OJ, Adekola MA, Azeez TO, Salami K, Onaolapo AY. 1-Methionine and silymarin: A comparison of prophylactic protective capabilities in acetaminophen-induced injuries of the liver, kidney and cerebral cortex. Biomed Pharmacother 2017; 85:323-333.

25. Onaolapo OJ, Ademakinwa OQ, Olalekan TO, Onaolapo AY. Ketamine-induced behavioural and brain oxidative changes in mice: an assessment of possible beneficial effects of zinc as mono- or adjunct therapy. Psychopharmacology (Berl) 2017; 234:2707-2725.

26. Onaolapo OJ, Paul TB, Onaolapo AY. Comparative effects of sertraline, haloperidol or olanzapine treatments on ketamineinduced changes in mouse behaviours. Metab Brain Dis 2017;32:1475-1489.

27. Onaolapo AY, Adebisi EO, Adeleye AE, Olofinnade AT, Onaolapo OJ. Dietary melatonin protects against behavioural, metabolic, oxidative, and organ morphological changes in mice that are fed high-fat, high- sugar diet. Endocr Metab Immune Disord Drug Targets 2020; 20:570-583.

28. Onaolapo OJ, Odeniyi AO, Jonathan SO, Samuel MO, Amadiegwu D, Olawale A, et al. An investigation of the antiParkinsonism potential of co-enzyme Q10 and co-enzyme Q10 /levodopa-carbidopa combination in mice. Curr Aging Sci 2019. doi: $10.2174 / 1874609812666191023153724$ 
29. Miller NJ, Rice-Evans C, Davies MJ, Gopinathan V, Milner A. A novel method for measuring antioxidant capacity and its application to monitoring the antioxidant status in premature neonates. Clin Sci (Lond) 1993; 84:407-412.

30. Ghiselli A, Serafini M, Natella F, Scaccini C. Total antioxidant capacity as a tool to assess redox status: critical view and experimental data. Free RadicBiol Med 2000; 29:1106.

31. Bartosz G. Non-enzymatic antioxidant capacity assays: limitations of use in biomedicine. Free Radic Res 2010; 44:711-720.

32. Pinchuk I, Shoval H, Dotan Y, Lichtenberg D. Evaluation of antioxidants: scope, limitations and relevance of assays. Chem Phys Lipids. 2012; 165:638-647.

33. Re R, Pellegrini N, Proteggente A, Pannala A, Yang M, RiceEvans C. Antioxidant activity applying an improved ABTS radical cation decolorization assay. Free Radic Biol Med 1999; 26:1231-1237.

34. Shea TB, Rogers E, Ashline D, Ortiz D, Sheu MS. Quantification of antioxidant activity in brain tissue homogenates using the 'total equivalent antioxidant capacity'. J Neurosci Methods 2003; 125:55-58.

35. Griffith WH. Nutritional factors affecting growth of rats on diets containing sodium benzoate. Exp Biol Med 1929; 26:858-860.

36. Saatci C, Erdem Y, Bayramov R, Akalın H, Tascioglu N, Ozkul Y. Effect of sodium benzoate on DNA breakage, micronucleus formation and mitotic index in peripheral blood of pregnant rats and their newborns. Biotechnol Biotechnol Equip 2016; 30:11791183.

37. Nair B. Final report on the safety assessment of Benzyl Alcohol, Benzoic Acid, and Sodium Benzoate. Int J Toxicol 2001; 20(Suppl.3):23-50.
38. Khasnavis S, Pahan K. Sodium benzoate, a metabolite of cinnamon and a food additive, upregulates neuroprotective Parkinson disease protein DJ-1 in astrocytes and neurons. J Neuroimmune Pharmacol 2012; 7:424-435.

39. Noorafshan A, Erfanizadeh M, Karbalay-Doust S. Sodium benzoate, a food preservative, induces anxiety and motor impairment in rats. Neurosciences (Riyadh) 2014; 19:24-28.

40. Modi KK, Roy A, Brahmachari S, Rangasamy SB, Pahan K. Cinnamon and its metabolite sodium benzoate attenuate the activation of p21rac and protect memory and learning in an animal model of alzheimer's disease. PLoS One 2015; 10:e0130398.

41. Crane SC, Lachance.PA The effect of chronic sodium benzoate consumption on brain monamines and spontaneous activity in rats. Nutr Rep Int 1985; 31:169-177.

42. Chen Q, Huang NN, Huang JT, Chen S, Fan J, Li C, et al. Sodium benzoate exposure downregulates the expression of tyrosine hydroxylase and dopamine transporter in dopaminergic neurons in developing zebrafish. Birth Defects Res B Dev Reprod Toxicol 2009; 86:85-91.

43. Tsay HJ, Wang YH, Chen WL, Huang MY, Chen YH. Treatment with sodium benzoate leads to malformation of zebrafish larvae. Neurotoxicol Teratol 2007; 29:562-569.

44. Fukui K, Onodera K, Shinkai T, Suzuki S, Urano S. Impairment of learning and memory in rats caused by oxidative stress and aging, and changes in antioxidative defense systems. Ann N Y Acad Sci 2001; 928:168-175.

45. Kandlur A, Satyamoorthy K, Gangadharan G. Oxidative stress in cognitive and epigenetic aging: a retrospective glance. Front $\mathrm{Mol}$ Neurosci 2020; 13:41. 